Military Technical College

Kobry El-Kobbah, Cairo, Egypt

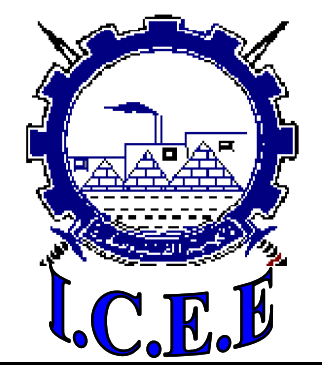

EE-4 $5^{\text {th }}$ International Conference on

Chemical \& Environmental

Engineering

\title{
GAMMA-RAY INDUCED CATALYTIC DEGRADATION OF METHYLENE BLUE IN AQUEOUS SUSPENSION OF TITANIA
}

\author{
Ahmed F. Twfik ${ }^{*}$, Ahmad A. Baraka*, Mohamed A. El-Sayed ${ }^{*}$ and Ahmad M. Omar ${ }^{*}$
}

\begin{abstract}
Gamma radiation-induced degradation of methylene blue (MB) in aqueous solution was studied for two groups: one with suspension of Titania, $\mathrm{TiO}_{2}$, photo-catalyst and the other without it. Degradation of methylene blue by gamma-rays (doses range: 200-1000 Gy) was investigated by measuring the change of absorbance spectrophotometrically at $\lambda_{\max }=661 \mathrm{~nm}$. Initial $\mathrm{pH}$ of solution (values 5, 7 and 9) was considered as a basic factor to study. The changes of $\mathrm{pH}$ values for irradiated methylene blue solutions with respect to gamma dose were recorded. Post irradiation effect was determined by measuring absorbance after 24 hours. For both groups, the color of methylene blue was bleached gradually with dose indicating its degradation. It was found that presence of $\mathrm{TiO}_{2}$ causes more bleaching. Also, as initial $\mathrm{pH}$ increases, the degradation increases. Methylene blue IR spectra, before and after irradiation, were recorded to investigate the effect of gamma radiation on MB.
\end{abstract}

\section{Keywords}

Gamma radiation, catalytic degradation, Methylene Blue, Titania.

\footnotetext{
${ }^{*}$ Egyptian Armed Forces
} 


\section{INTRODUCTION}

Nowadays, several activities produces large amounts of organic wastes, most of which have a harmful effect on human, and find its way to water mass such as rivers, lakes and even underground water resources. Specifically, textile industries are known to discharge considerable amounts of non fixed dyes. About $15 \%$ of the total world's production of dyes leaks during the process of dyeing and is released in effluents. It is well known that some of these dyes are highly carcinogenic [1,2]

Methylene blue is as an organic pollutant because of its wide use in many industrial applications as well as many uses in a biology and chemistry [3]. It is a heterocyclic aromatic chemical compound with molecular formula: $\mathrm{C}_{16} \mathrm{H}_{18} \mathrm{~N}_{3} \mathrm{SCl}$, Figure 1. At room temperature, it appears as a solid, odorless, dark green powder, that yields a blue solution when dissolved in water. The hydrated form has 3 molecules of water per molecule of methylene blue. In present study, this compound was selected for decontamination as a good representative for organic dye pollutants. [4]

Gamma irradiation of solutions containing organic pollutants is a very promising technique for decontamination by degradation [5]. A considerable number of researches on application of radiation have shown that ionizing radiation, such as gamma radiation and electron beam, is effective for the degradation of many organic pollutants which are biologically resistant in water [6]. Practically, an industrial plant for treating $10000 \mathrm{~m}^{3}$ per day of textile dyeing wastewater with electron beam $(1 \mathrm{MeV}, 400 \mathrm{~kW})$ has been constructed in the city of Daegu (Korea) with the support of International Atomic Energy Agency and Korean government [7].

Photocatalysis is another effective well established technique to remediate water by degrading organic pollutant and it is of interest because of its rapid increasing applications over the last 20 years [8]. Its effectiveness stems from strong redox chemical reactions. This technique deploys the use of sun light or different wave lengths of ultra-violet sources.

Semiconductor materials are typical photocatalysts for this type of reactions. The commonly used photocatalysts are $\mathrm{TiO}_{2}, \mathrm{ZnO}, \mathrm{CdS}, \mathrm{ZnS}, \mathrm{SrTiO}_{3}$ and $\mathrm{Fe}_{2} \mathrm{O}_{3}$. There are many photocatalysts beside these mentioned; however, $\mathrm{TiO}_{2}$ (or Titania) is the most active for organic compounds degradation processes as frequently reported and applied [9]. In water treatment processes, $\mathrm{TiO}_{2}$ shows non-toxicity and insolubility, both in the dark and on illumination, which are important considerations. [10]. Figure 2 shows the principle of photodegradation of organic compounds using a photocatalyst.

In this work, coupling of ionizing radiation, other than ultra-violet, such as gamma and semiconductor material $\left(\mathrm{TiO}_{2}\right)$ was investigated to claim its powerful effect in organic pollutant degradation. Gamma-rays source $\left(\mathrm{Co}^{60}\right)$ was used instead of ultra-violet sources as $\mathrm{TiO}_{2}$-activating electromagnetic radiation. Gamma rays of 1.1732 and $1.3325 \mathrm{MeV}$, (from $\mathrm{Co}^{60}$ source) are highly ionizing and it is thought that it can activate $\mathrm{TiO}_{2}$ in the same way as ultra-violet does. To our knowledge and after thorough search, this coupling (gamma radiation and a semiconductor $\left(\mathrm{TiO}_{2}\right)$ for such applications has not been investigated yet.

To elucidate this decontamination power, the degradation and mineralization of methylene blue in aqueous solutions were investigated using gamma-irradiation in two different reaction groups; one in the presence of $\mathrm{TiO}_{2}$ and the other without it. The change of absorption spectra 
of methylene blue with gamma-dose, i.e. degradation efficiency, for each group was investigated with respect to solution initial $\mathrm{pH}$ change.

\section{Experimental}

\subsection{Sample preparation}

Methylene blue (BDH chemicals ltd poole England), bi-distilled water as a solvent, diluted $\mathrm{HCl}$ acid and diluted $\mathrm{NaOH}$ to adjust $\mathrm{pH}$ (Hanna instrument) and $\mathrm{TiO}_{2}$ powder (El-Nasr Co.) were materials used to prepare samples. For the first group of samples: each sample was a plastic vial that contains $(40 \mathrm{ml})$ of methylene blue aqueous solution (of concentration $0.5 \times 10^{-4} \mathrm{M}$ ). The vial was then introduced into gamma cell (Indian type (Gamma Chamber 5000 ), rate $=2.1 \mathrm{kGy} / \mathrm{hr}$ ) to expose to steady state radiolysis. For the second group of samples: samples were prepared as before and, $0.25 \mathrm{~g}$ of $\mathrm{TiO}_{2}$-powder was added $(6.25 \mathrm{~g} / \mathrm{l})$. The vial containing Titania suspension was then stirred in the dark for about 30 minutes before gamma-irradiation exposure to ensure equilibration and homogenous distribution. The used Titania has the following properties: average particle size, $d_{\mathrm{ave}}=30 \mathrm{~nm}$, specific surface area, $S_{\mathrm{BET}}=55 \mathrm{~m}^{2} / \mathrm{g}$ and percentage of anatase $=70 \%$. (El-Nasr Co.data)

\section{2 degradation measurement}

Methylene blue degradation was detected by measuring the absorbance of irradiated samples at $\lambda_{\max }=661 \mathrm{~nm}$, using UV-Vis (Shimatzu UV-160) spectrophotometer. All spectrophotometrically measurements were carried out at ambient temperature using quartz cells with $1 \mathrm{~cm}$ optical path length. A calibration curve was previously determined to calculate the concentration of methylene blue residue in solutions. The $\mathrm{pH}$ value for each sample was also determined after gamma irradiation using (Hanna instrument).

\subsection{FTIR Analysis}

For a preliminary investigation of the radiolytic products, selected irradiated samples (with and without $\mathrm{TiO}_{2}$ ) and a non-irradiated sample of methylene blue were analyzed using FTIR technique employing (Shimatzu FTIR 8400). The spectra were compared to determine the change in structure and the produced groups.

\section{Results and discussion}

\subsection{Degradation of methylene blue in the absence of $\mathrm{TiO}_{2}$ \\ 3.1.1 Bleaching with dose}

The absorbance against dose for samples prepared at $\mathrm{pH} \mathrm{5,7}$ and 9 are shown in Figure 3. It is clear that absorbance decreased, i.e. bleaching increased, as dose increased from $200-1000$ Gy for the three $\mathrm{pH}$ values. This bleaching is due to degradation and mineralization of methylene blue. Also, as initial $\mathrm{pH}$ increases each dose value, the absorbance at $\lambda_{\max }$ decreases indicating more degradation. Table 1 elucidates this numerically.

Since MB is a dilute aqueous solution, it is expected that the chemistry of water may control the degradation process. The radiolysis of water is very well documented and it has been known that it produces $\left(\mathrm{H}_{2}\right),\left(\mathrm{H}_{2} \mathrm{O}_{2}\right),\left(\mathrm{H}^{+}\right),\left(\mathrm{OH}^{-}\right)$besides hydrated electron $\left(\mathrm{e}_{\mathrm{aq}}{ }^{-}\right)$, hydroxyl radical $(\mathrm{OH})$ and hydrogen atom $(\mathrm{H})$ as intermediate species in varying amounts depending upon the linear energy transfer value of the radiation.[10] In dilute solutions the yield of these species are as follows: $G\left(\mathrm{e}_{\mathrm{aq}}{ }^{-}\right)=G(\mathrm{OH})=0.28$ and $G\left({ }^{\circ} \mathrm{H}\right)=0.06 \mu \mathrm{mol} / \mathrm{J}$. These intermediates can then take part in many different reactions with the solute molecule (in our case $\mathrm{MB}$ ) thereby causing a change in its composition [11] 
The hydrated electron $\left(\mathrm{e}_{\mathrm{aq}}{ }^{-}\right)$and the hydrogen radical $(\mathrm{H})$ are the main reductive species produced in irradiated aqueous solution, whereas, the hydroxyl radicals ( $\mathrm{OH})$ and perhydroxyl radicals $\left(\mathrm{HO}_{2}\right.$, produced in subsequent reactions) are the main oxidizing species produced in water radiolysis. One of the consequences of radiolysis in aqueous solutions is that the charged species become hydrated within a very short interval of time $\left(10^{-11}\right.$ seconds), e.g. formation of $\mathrm{e}_{\mathrm{aq}}{ }^{-} \cdot[11]$

In dilute aqueous solutions, most of radiation energy is practically absorbed by water molecules. Accordingly, the change in solute composition would essentially results from the secondary reactions of radiation induced species from water and solute molecules rather than the direct effect of radiation on the solute molecules. These secondary reactions arise from the reactions of solutes with the oxidizing and reducing species initially produced during water radiolysis [12]

As all solutions in this study were not de-aerated, irreversible oxidative degradation mechanism could be suggested $[13,14]$.

The $\mathrm{OH}$ radical is the active oxidizing radical in this mechanism according to the degradation pathway of methylene blue provided by Houas et al [15] i.e. $\mathrm{OH}$ radical makes the main contribution to degradation of methylene blue and its intermediates. Since MB is cationic and not electron donor, the initial step of $\mathrm{MB}$ degradation could be ascribed to the cleavage of $\mathrm{C}-$ $\mathrm{S}^{+}=\mathrm{C}$ bonds in the functional group in $\mathrm{MB}$ :

$\mathrm{R}-\mathrm{S}^{+}=\mathrm{R}^{\prime}+\cdot \mathrm{OH} \rightarrow \mathrm{R}-\mathrm{S}(=\mathrm{O})-\mathrm{R}^{\prime}+\mathrm{H}^{+}$

The sulfoxide group can undergo a second attack by an $\cdot \mathrm{OH}$ radical producing the sulfone and causing the definitive dissociation of two benzenic rings:

$\mathrm{NH}_{2}-\mathrm{C}_{6} \mathrm{H}_{3}(\mathrm{R})-\mathrm{S}(=\mathrm{O})-\mathrm{C}_{6} \mathrm{H}_{4}-\mathrm{R}+\cdot \mathrm{OH} \rightarrow \mathrm{NH}_{2}-\mathrm{C}_{6} \mathrm{H}_{3}(\mathrm{R})-\mathrm{SO}_{2}+\mathrm{C}_{6} \mathrm{H}_{5}-\mathrm{R}$

and/or

$\mathrm{NH}_{2}-\mathrm{C}_{6} \mathrm{H}_{3}(\mathrm{R})-\mathrm{S}(=\mathrm{O})-\mathrm{C}_{6} \mathrm{H}_{4}-\mathrm{R}+\cdot \mathrm{OH} \rightarrow \mathrm{NH}_{2}-\mathrm{C}_{6} \mathrm{H}_{4}-\mathrm{R}+\mathrm{SO}_{2}-\mathrm{C}_{6} \mathrm{H}_{4}-\mathrm{R}$

Subsequently, the sulfone may be attacked by a third $\cdot \mathrm{OH}$ radical giving a sulfonic acid:

$\mathrm{SO}_{2}-\mathrm{C}_{6} \mathrm{H}_{4}-\mathrm{R}+\cdot \mathrm{OH} \rightarrow \mathrm{R}-\mathrm{C}_{6} \mathrm{H}_{4}-\mathrm{SO}_{3} \mathrm{H}$.

Finally release of $\mathrm{SO}_{4}{ }^{2-}$ ions may be attributed to a fourth attack by $\cdot \mathrm{OH}$ :

$\mathrm{R}-\mathrm{C}_{6} \mathrm{H}_{4}-\mathrm{SO}_{3} \mathrm{H}+\cdot \mathrm{OH} \rightarrow \mathrm{R}-\cdot \mathrm{C}_{6} \mathrm{H}_{4}+\mathrm{SO}_{4}{ }^{2-}+2 \mathrm{H}^{+}$

The amino group in $\mathrm{MB}$ could be substituted by an $\cdot \mathrm{OH}$ radical, forming the corresponding phenol and releasing a $\cdot \mathrm{NH}_{2}$ radical which generates ammonia and ammonium ions, estimated to be primary products.

$\mathrm{R}-\mathrm{C}_{6} \mathrm{H}_{4}-\mathrm{NH}_{2}+\cdot \mathrm{OH} \rightarrow \mathrm{R}-\mathrm{C}_{6} \mathrm{H}_{4}-\mathrm{OH}+\cdot \mathrm{NH}_{2}$

$\cdot \mathrm{NH}_{2}+\cdot \mathrm{H} \rightarrow \mathrm{NH}_{3}$ 
This mechanism shows production of $\mathrm{H}^{+}$in steps (1) and (5) which causes acidity. However, steps (7) and (8) show production of alkalinity sources. It could be suggested that the overall change in $\mathrm{pH}$ is null and this can be determined stichiometerically by balancing the products with $\mathrm{S}$ and $\mathrm{N}$ atoms present in $\mathrm{MB}$ structure.

\subsubsection{Effect of gamma dose on $\mathrm{pH}$ value}

After irradiation of different samples of different initial $\mathrm{pH}$ values, the $\mathrm{pH}$ was measured. It was found that $\mathrm{pH}$ did not change significantly after irradiation for all studied doses. Figure 4.

We may conclude that degradation did not produce any net $\mathrm{pH}$-affecting ions such as $\mathrm{OH}^{-}$or $\mathrm{H}^{+}$or any other similar moieties, which consides with the suggested mechanism fulfills this behavior.

\subsection{Methylene blue at different $\mathrm{pH}$ values in the presence of $\mathrm{TiO}_{2}$ \\ 3.2.1 Bleaching with dose}

The irradiation results of $\mathrm{MB}$ in the presence of $\mathrm{TiO}_{2}$ for the three different initial $\mathrm{pH}$ values 5, 7, and 9 are shown in Figure 5 and Table 2. All samples showed bleaching the alkaline sample ( $\mathrm{pH}$ 9) was more bleached than the other two $\mathrm{pH}$ values (5 and 7). This is similar to the results without $\mathrm{TiO}_{2}$. On the other hand bleaching of $\mathrm{pH}$ values 5 and 7 samples showed some crossings.

Table 3 showed that the $\Delta$ abs. values for samples with $\mathrm{TiO}_{2}$ are higher than without it .this means that coupling of gamma ionizing radiation with semiconductor material positively affected the degradation process.

\subsection{Effect of gamma dose on ( $\mathrm{pH}$ values)}

After irradiation of different samples of different initial $\mathrm{pH}$ values, in the presence of $\mathrm{TiO}_{2}$ the $\mathrm{pH}$ was measured. The alkaline and acidic samples showed a change to neutrality for all studied doses. The neutral samples remain almost within the same values. [Table 4 and clearly depicted in Figure 6]. This phenomenon is in marked contrast to degradation of methylene blue without presence of $\mathrm{TiO}_{2}$.

This result is opposite to the results obtained in the absence of $\mathrm{TiO}_{2}$, which indicates the contribution of $\mathrm{TiO}_{2}$ thus the behavior in dilute solutions must be considered. The point of zero charge of $\mathrm{TiO}_{2}$ is $\mathrm{pH}_{\mathrm{pzc}}=6.0$ to 6.8 and this property controls the degree of adsorption of pollutant on $\mathrm{TiO}_{2}$ surface, especially when it has ionic (cationic or anionic structure). In aqueous media, the surface of $\mathrm{TiO}_{2}$ is charged according to $\mathrm{pH}$ of media as follows;

Case 1: At pH $>\mathrm{pH}_{\mathrm{pzc}}: \mathrm{Ti}-\mathrm{OH}+\mathrm{OH}^{-} \leftrightarrow \mathrm{TiO}^{-}+\mathrm{H}_{2} \mathrm{O}$

Case 2: At $\mathrm{pH}<\mathrm{pH}_{\mathrm{pzc}}$ : Ti-OH $+\mathrm{H}^{+} \leftrightarrow \mathrm{TiOH}_{2}{ }^{+}$

Since MB is a cationic dye, it is conceivable that at $\mathrm{pH}>\mathrm{pH}_{\mathrm{pzc}}$, its adsorption is favored on a negatively charged surface. On the contrary; for $\mathrm{pH}<\mathrm{pH}_{\mathrm{pzc}}$, adsorption is hindered.

Consequently, the degradation mechanism could be suggested to differ according to $\mathrm{pH}$ as follows: 
For Case $1, \mathrm{pH}>\mathrm{pH}_{\mathrm{pzc}}, \mathrm{MB}$ is adsorbed on $\mathrm{TiO}_{2}$-surface. The photo-ejected $\mathrm{e}^{-}$has the direct opportunity to react with the main colur centre of methylene blue, $=\mathrm{S}^{+}-$of $\mathrm{MB}$ (instead of being captured by $\mathrm{O}_{2}$ present in water), which led to initial reductive destruction of this group and consequently colur bleaches.thus The suggested reaction is as follows;

$\mathrm{S}^{+}-+\mathrm{e}^{-}$
$\mathrm{H}_{2} \mathrm{O}+\mathrm{h}_{\mathrm{s}}^{+} \longrightarrow \mathrm{S}^{-}-\mathrm{H}+\mathrm{OH}^{-}$
$\mathrm{OH}^{+}+\mathrm{OH}^{\cdot} \longrightarrow \mathrm{H}_{\mathrm{aq}}^{+}+\mathrm{OH}^{+}$

The produced $\mathrm{H}_{2} \mathrm{O}_{2}$ has oxidative degradation effect on $\mathrm{MB}$. The overall consequence is initial reductive destruction by $\mathrm{e}^{-}$, subsequent oxidative destruction by $\mathrm{H}_{2} \mathrm{O}_{2}$, and release of $\mathrm{H}_{\mathrm{aq}}{ }^{+}$which decreases the $\mathrm{pH}$ as observed. Generally in this case, the destruction is reductive / oxidative one.

In this case we may suggest that bleaching is a two step process, adsorption of $\mathrm{MB}$ on $\mathrm{TiO}_{2}$ followed by degradation reaction with activation products of $\mathrm{TiO}_{2}$ while the contribution of radiolytic products of water is limited.

For Case 2, $\mathrm{pH}<\mathrm{pH}_{\mathrm{pzc}}$, adsorption of $\mathrm{MB}$ on $\mathrm{TiO}_{2}$-surface is hindered. The effect of gamma radiation on $\mathrm{TiO}_{2}$ would be similar to that of ultra-violet:

$\mathrm{TiO}_{2} \stackrel{\text { gamma }}{\longrightarrow} \mathrm{h}_{\gamma}^{+}+\mathrm{e}_{\mathrm{aq}}^{-}$

As the solution was not de-aerated, then;

$$
\mathrm{e}_{\mathrm{aq}}{ }^{-}+\mathrm{O}_{2} \longrightarrow \mathrm{O}_{2}^{-}
$$

The previous two steps prevent the recombination of $\mathrm{h}_{\gamma}{ }^{+}$and $\mathrm{e}_{\mathrm{aq}}{ }^{-}$, enabling $\mathrm{h}_{\gamma}{ }^{+}$to oxidize the dye molecule. Furthermore, the produced $\mathrm{O}_{2}{ }^{-}$moluclar ion are powerful oxidants $[12,13]$, and can also oxidatively degrade the dye. The oxidative degradation by $\mathrm{h}_{\gamma}{ }^{+}$and $\mathrm{O}_{2}{ }^{-}$originates from $\mathrm{TiO}_{2}$ surface. As $\mathrm{MB}$ in this case is not adsorbed on $\mathrm{TiO}_{2}$ surface, further degradation occurs by radiolytic product of water. In this case, it is more difficult to trace the origin of $\mathrm{pH}$ increase to neutrality.

In general, it is essential to take into account that water radiolysis-products may play relative role in the degradation of $\mathrm{MB}$ and in affecting the solution $\mathrm{pH}$ for the different conditions (with and without $\mathrm{TiO}_{2}$ ). This picture makes it difficult to assign exactly the mechanisms for each set of conditions present in this work (irradiation: without $\mathrm{TiO}_{2}$, with $\mathrm{TiO}_{2}$ with alkaline media, with $\mathrm{TiO}_{2}$ with acidic media and with $\mathrm{TiO}_{2}$ with neutral media). The previous suggested mechanisms are primary ones depending on $\mathrm{pH}$ and absorbance and IR data collected. To get a more idea about the 2 suggested mechanisms, more analysis is required during radiolysis. Pulse radiolysis is seems too precise to be suitable tool and this will be considered in a future work.

\subsection{Degradation of methylene blue in the absence of $\mathrm{TiO}_{2}$ (after $24 \mathrm{hrs}$ of Irradiation)}

Absorbance against doses for the different $\mathrm{pH}$ values, are shown in Figure 7. $\mathrm{MB}$ at $\mathrm{pH} 9$ is more bleached than at $\mathrm{pH} 7$ and 5. Form Table 5, more bleaching was observed when compared with samples measured just after irradiation, [Table 1]. This is a positive result form the decontamination point of view. 


\subsection{Degradation of the methylene blue in the presence of $\mathrm{TiO}_{2}$ (after $24 \mathrm{hrs}$ of irradiation)}

Absorbance against doses for the different $\mathrm{pH}$ values, are shown in Figure 8. Again, as for without $\mathrm{TiO}_{2}$ (section 3-3), MB suffers bleaching at $\mathrm{pH} 9$ more than at $\mathrm{pH} 7$ and 5. Compared with similar samples measured just after irradiation, there is more bleaching was recorded. [Table 6 when compared with Table 2], this gives more effectiveness. For the decontamination process

\subsection{FTIR analysis}

Figure 9 shows the IR spectra of $\mathrm{MB}, \mathrm{MB}$ without $\mathrm{TiO}_{2}$ irradiated at $1000 \mathrm{~Gy}$ and $\mathrm{MB}$ with $\mathrm{TiO}_{2}$ irradiated at $1000 \mathrm{~Gy}$. In the figure, the spectra of $\mathrm{MB}$ without $\mathrm{TiO}_{2}$ irradiated by 1000 Gy and $\mathrm{MB}$ with $\mathrm{TiO}_{2}$ irradiated by 1000 Gy are very similar indicating the same degradation effects and products. while They are markedly different from that of MB. The main bands and peaks of MB are as follows: the absorption band at 1600.8 and $1357 \mathrm{~cm}^{-1}$ correspond to the vibration of the aromatic ring. The bands observed at about $2920-2850 \mathrm{~cm}^{-1}$ could be assigned to the aliphatic $\mathrm{C}-\mathrm{H}$ groups. $\mathrm{C}-\mathrm{N}$ stretch is present at $1357.8 \mathrm{~cm}^{-1}$. From the other two spectra it can be deduced that gamma-degradation (with and without $\mathrm{TiO}_{2}$ ) have, qualitatively, the same effect. Some functional groups either disappeared or diminished such as at $1253.6,1141.8,887.2$ and $833.2 \mathrm{~cm}^{-1}$. [16-17].

\section{Conclusion}

It was found that the $\mathrm{pH}$ adjustment is very important in the degradation of Methylene blue as the more degradable samples were the ones prepared at $\mathrm{pH} \mathrm{9,} \mathrm{also} \mathrm{the} \mathrm{presence} \mathrm{of} \mathrm{TiO}_{2}$ was great importance as it catalyses the degradation of Methylene blue using gamma radiation at pH 9 more than the samples without $\mathrm{TiO}_{2}$, as Methylene blue was completely degradated at 1000 Gy. Finally the presence of $\mathrm{TiO}_{2}$ caused the degradation of $\mathrm{MB}$ using gamma radiation to be complete

\section{References}

[1] M.A. Brown, S.C. De Vito, Crit. Rev. Environ. Sci. Technol. 23 (1993) 249-324.

[2] H. Zollinger (Ed.), Color Chemistry. Synthesis, Properties and Applications of Organic Dyes and Pigments, 2nd Revised Edition, VCH, 1991.

[3] F. Abdullah, M.A. Rauf, S.S. Ashraf, Photolytic oxidation of Safranin-O with $\mathrm{H}_{2} \mathrm{O}_{2}$, Dyes and Pigments 72 (2007) 349-352.

[4] F.J. Benitez, F.J. Real, J.L. Acero, A.I. Leal, C. Garcia, Gallic acid degradation in aqueous solutions by $\mathrm{UV} / \mathrm{H}_{2} \mathrm{O}_{2}$ treatment, Fenton's reagent and the photo-Fenton, system, Journal of Hazardous Materials 126 (2005) 31-39.

[5] Chiaki Ogino, Mahmoud Farshbaf Dadjour, Yasuo Iida, Nobuaki Shimizu Decolorization of methylene blue in aqueous suspensions of titanium peroxide(2008)

[6] Hinda Lachheb, Eric Puzenat, Ammar Houas, Mohamed Ksibi, Elimame Elaloui, Chantal Guillard, Jean-Marie Herrmann, Photocatalytic degradation of various types of dyes (Alizarin S, Crocein Orange G, Methyl Red, Congo Red, Methylene Blue) in water by UV-irradiated titania (2002) 
[7] Pelizzetti and M. Schiavello (eds.), Photochemical Conversion and Storage of Solar Energy, Kluwer Academic, 1991, p. 251.

[8] M.E. Fabiyi, R.L. Skelton, J. Photochem. Photobiol., A: Chem. 129 (1999) 17-24.

[9] Pelizzetti and M. Schiavello (eds.), Photochemical Conversion and Storage of Solar Energy, Kluwer Academic, 1991, p. 251.

[10] T. Palfi, E. Takacs, L. Wojnarovits, Degradation of $\mathrm{H}$-acid and its derivative in aqueous solution by ionizing radiation, Water Research 41 (2007) 2533-2540.

[11] M.A. Rauf, S.S. Ashraf / Journal of Hazardous Materials 166 (2009) 6-16.

[12] A. KOVÁCS, L. WOJNÁOVITS, Large-scale dosimetry using dilute methylene blue dye in aqueous solution, Radiat. Phys. Chem. Vol. 52. No I 6, pp. 539 542, 1998

[13] S. Lakshmiet al. / J. Photochem. Photobiol. A." Chem. 88 (1995) 163-167

[14] H. Lachheb et al. / Applied Catalysis B: Environmental 39 (2002) 75-90

[15] Houas A, Lachheb H, Ksibi M, et al. Photocatalytic Degradation Pathway of Methylene Blue in Water [J]. Appl. Catal. B: Environ., 2001, 31(2): 145-157.

[16] Chamnan Randorn, Sumpun Wongnawab and Phadoong Boonsinb "Bleaching of Methylene Blue by Hydrated Titanium Dioxide" Science Asia 30 (2004): 149-156.

[17] Sudhir S. Arbuja, Ranjit R. Hawaldarb, Uttamrao P. Mulikb, Bina N. Wanic, Dinesh P. Amalnerkarb, Suresh B. Waghmodea" Preparation, characterization and photocatalytic activity of $\mathrm{TiO}_{2}$ towards methylene blue degradation" Materials Science and Engineering (2009).

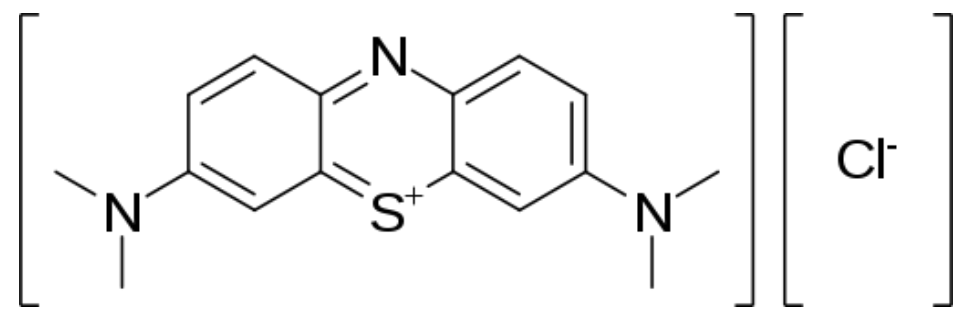

Figure 1: Chemical structure of methylene blue 


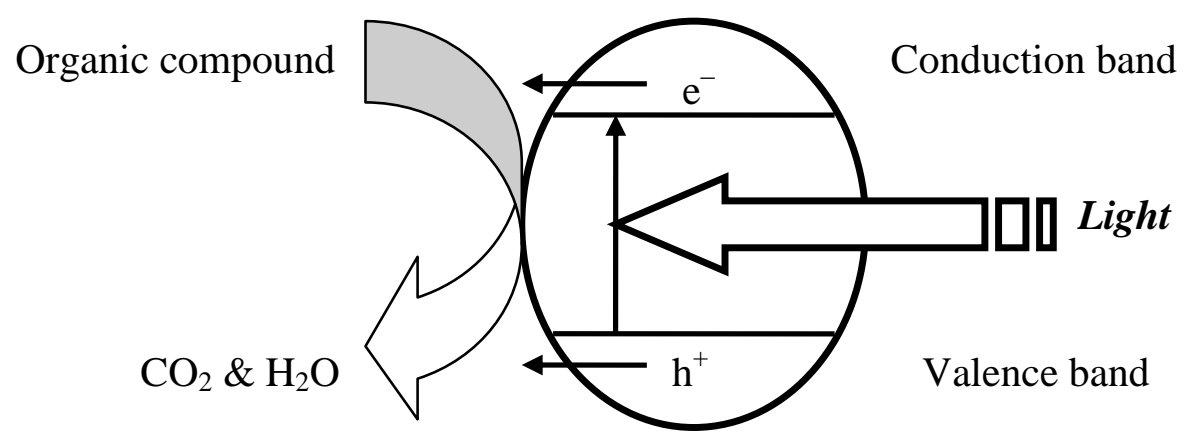

Photocatalyst

particle

Figure 2: General mechanism of photocatalytic degradation of organic compounds

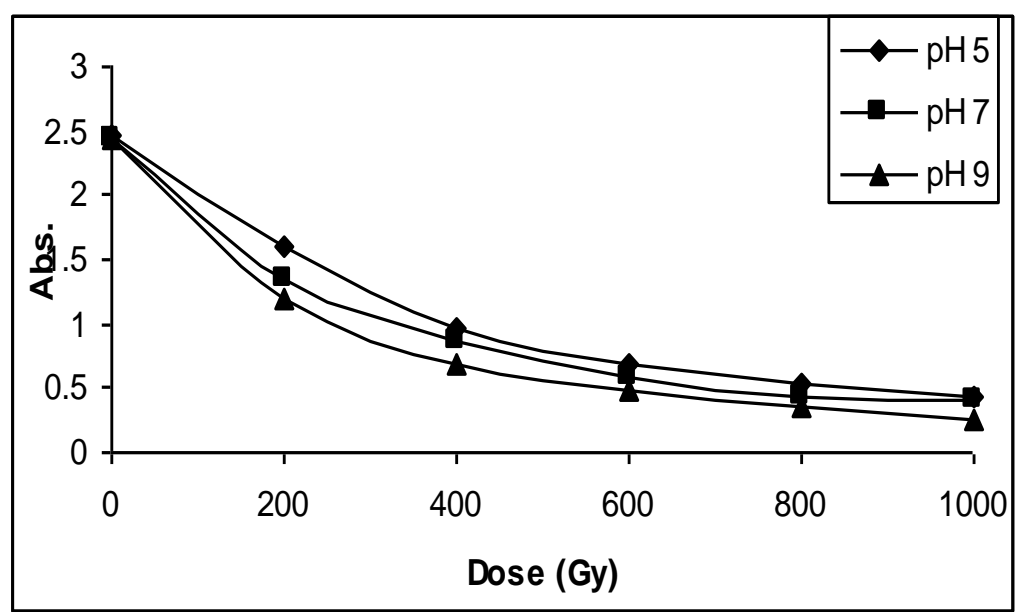

Figure 3: Change of MB absorbance with gamma dose at $\mathrm{pH} \mathrm{5,7}$ and 9 (without $\mathrm{TiO}_{2}$ ).

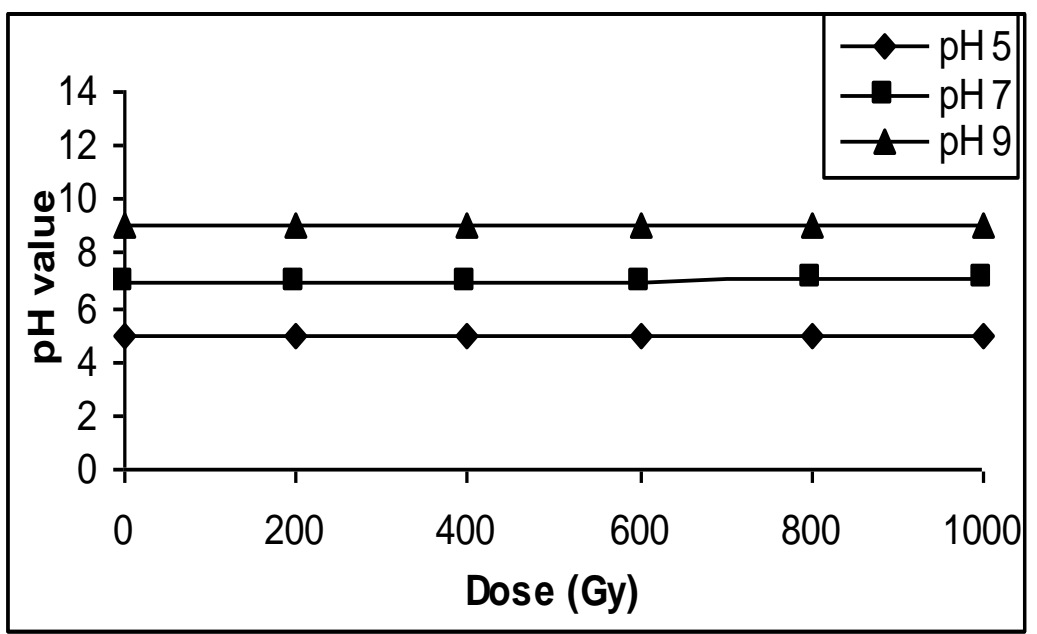

Figure 4: Change in $\mathrm{pH}$ values with gamma dose (without $\mathrm{TiO}_{2}$ ). 


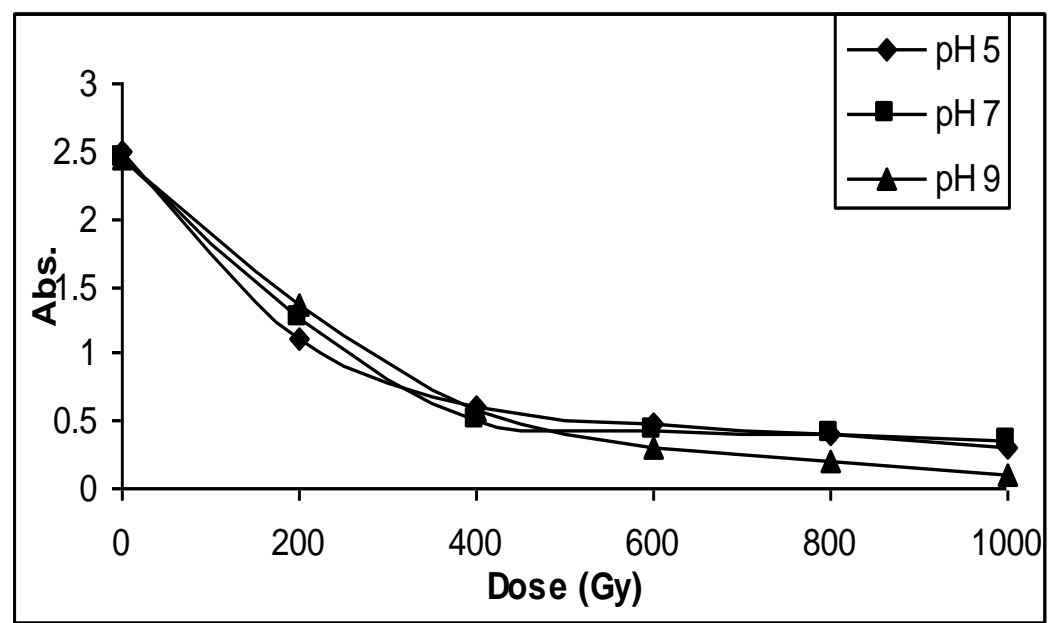

Figure 5: Change of $\mathrm{MB}$ absorbance with gamma dose at $\mathrm{pH} \mathrm{5,7}$ and 9 (with $\mathrm{TiO}_{2}$ ).

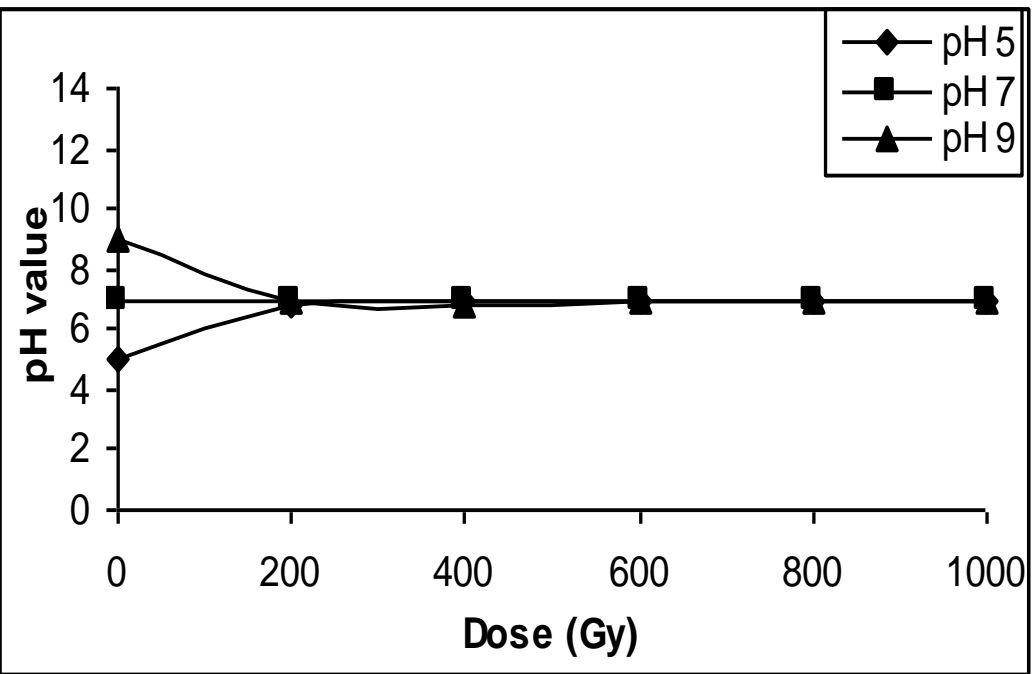

Figure 6: Change in $\mathrm{pH}$ values with gamma dose (with $\mathrm{TiO}_{2}$ ). 


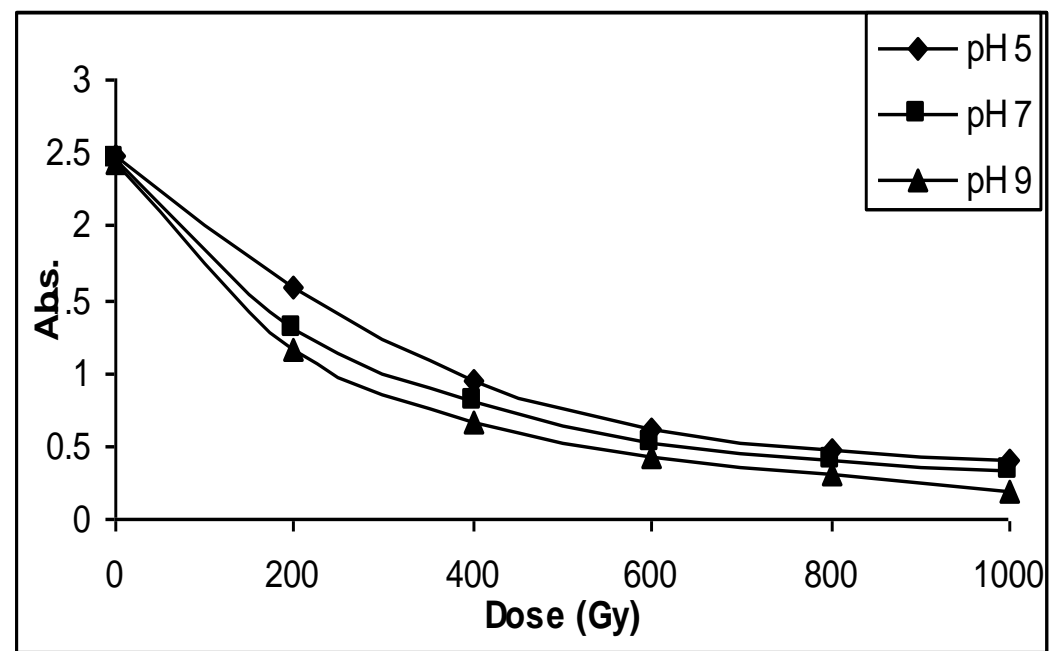

Figure 7: variation of $\mathrm{MB}$ absorbance after 24 hours of gamma irradiation (without $\mathrm{TiO}_{2}$ )

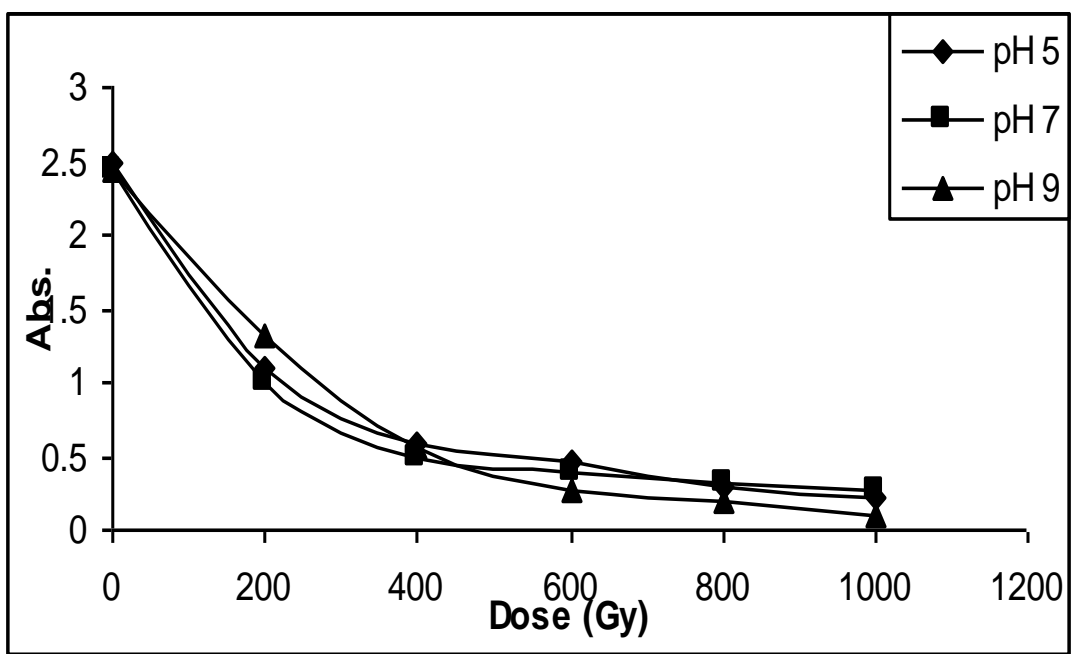

Figure 8: variation of $\mathrm{MB}$ absorbance after 24 hours of gamma irradiation (with $\mathrm{TiO}_{2}$ ) 

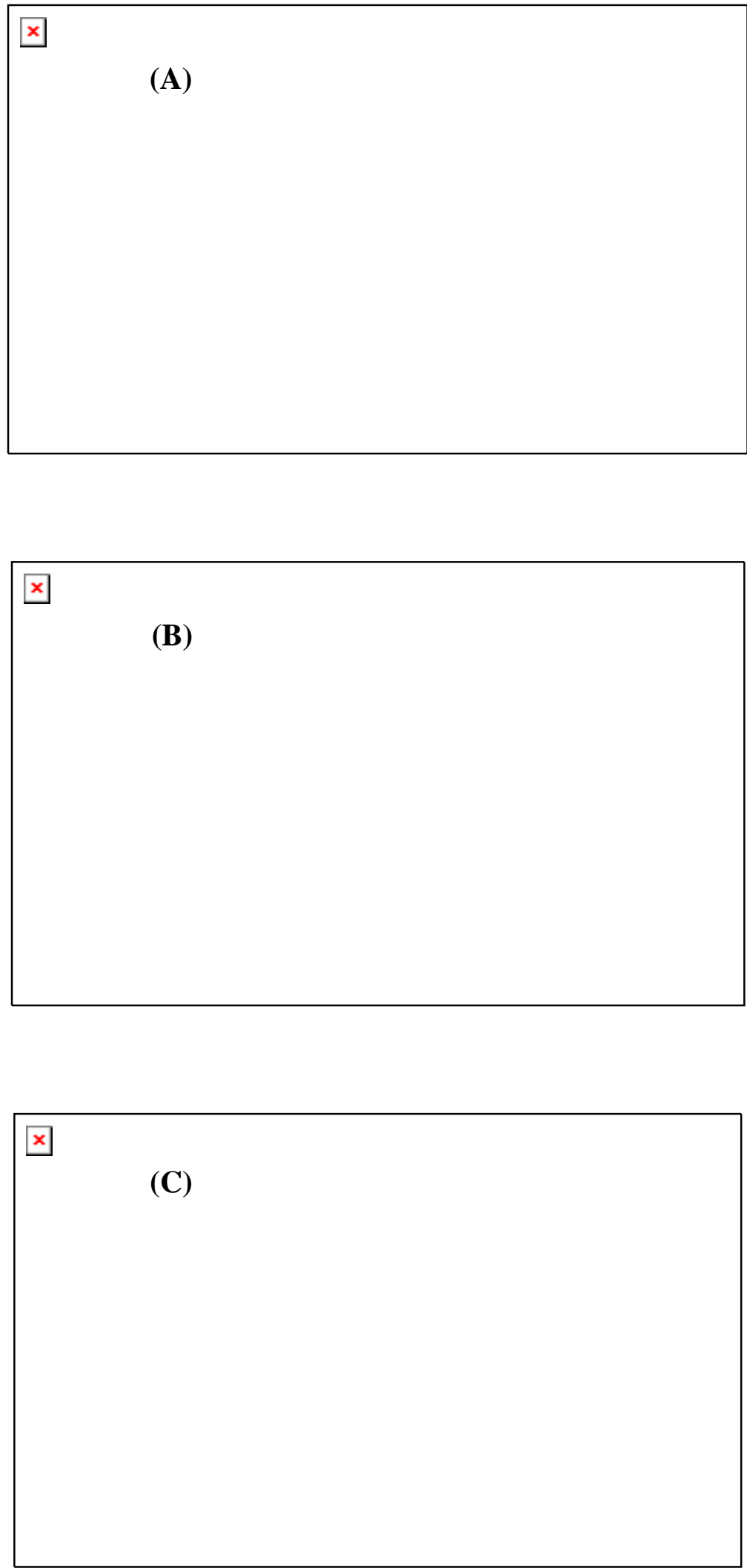

Figure 9: IR spectra of (A) MB, (B) MB without TiO2 irradiated at $1000 \mathrm{~Gy}$ and (C) MB with $\mathrm{TiO}_{2}$ irradiated at $1000 \mathrm{~Gy}$. 
Table 1: Absorbance of methylene blue against gamma doses

\begin{tabular}{|c|c|c|c|}
\hline Dose (Gy) & pH 5 & pH 7 & pH 9 \\
\hline 0 & 2.478 & 2.453 & 2.429 \\
\hline 200 & 1.602 & 1.348 & 1.200 \\
\hline 400 & 0.973 & 0.854 & 0.680 \\
\hline 600 & 0.679 & 0.587 & 0.480 \\
\hline 800 & 0.546 & 0.435 & 0.355 \\
\hline 1000 & 0.444 & 0.401 & 0.252 \\
\hline
\end{tabular}

Table 2: Absorbance of methylene blue (with $0.25 \mathrm{~g}$ of $\mathrm{TiO}_{2}$ ) against gamma doses

\begin{tabular}{|c|c|c|c|}
\hline Dose (Gy) & pH 5 & pH 7 & pH 9 \\
\hline 0 & 2.496 & 2.445 & 2.440 \\
\hline 200 & 1.106 & 1.271 & 1.353 \\
\hline 400 & 0.615 & 0.500 & 0.586 \\
\hline 600 & 0.474 & 0.420 & 0.295 \\
\hline 800 & 0.400 & 0.410 & 0.200 \\
\hline 1000 & 0.303 & 0.350 & 0.090 \\
\hline
\end{tabular}

Table 3: comparison between $\Delta \mathrm{Abs}$. values for samples at different $\mathrm{pH}$ values and doses

\begin{tabular}{|c|c|c|c|c|c|c|}
\hline \multirow{3}{*}{$\begin{array}{l}\text { Dose } \\
(G y)\end{array}$} & \multicolumn{2}{|c|}{ pH 5} & \multicolumn{2}{|c|}{ pH 7} & \multicolumn{2}{|c|}{ pH 9} \\
\hline & \multicolumn{6}{|c|}{$\Delta$ Abs. } \\
\hline & $\begin{array}{c}\text { Without } \\
\mathrm{TiO}_{2}\end{array}$ & $\begin{array}{l}\text { With } \\
\mathrm{TiO}_{2}\end{array}$ & $\begin{array}{c}\text { Without } \\
\mathrm{TiO}_{2}\end{array}$ & $\begin{array}{l}\text { With } \\
\mathrm{TiO}_{2}\end{array}$ & $\begin{array}{c}\text { Without } \\
\mathrm{TiO}_{2}\end{array}$ & $\begin{array}{l}\text { With } \\
\mathrm{TiO}_{2}\end{array}$ \\
\hline 200 & 0.876 & 1.39 & 1.105 & 1.174 & 1.229 & 1.087 \\
\hline 400 & 1.505 & 1.881 & 1.599 & 1.945 & 1.749 & 1.854 \\
\hline 600 & 1.799 & 2.022 & 1.866 & 2.025 & 1.949 & 2.154 \\
\hline 800 & 1.932 & 2.096 & 2.018 & 2.035 & 2.074 & 2.24 \\
\hline 1000 & 2.034 & 2.193 & 2.025 & 2.093 & 2.177 & 2.35 \\
\hline
\end{tabular}

Table 4: $\mathrm{pH}$ values after irradiation at different gamma doses

\begin{tabular}{|c|c|c|c|}
\hline \multirow{2}{*}{ Dose, Gy } & Initial pH 5 & Initial pH 7 & Initial pH 9 \\
\cline { 2 - 4 } & \multicolumn{3}{|c|}{ pH After irradiation } \\
\hline 200 & 6.86 & 6.96 & 6.93 \\
\hline 400 & 6.90 & 6.93 & 6.86 \\
\hline 600 & 6.89 & 6.98 & 6.95 \\
\hline 800 & 6.91 & 6.99 & 6.91 \\
\hline 1000 & 6.92 & 6.94 & 6.89 \\
\hline
\end{tabular}


Table 5: Absorbance of methylene blue for post irradiation after 24 hours without $\mathrm{TiO}_{2}$

\begin{tabular}{|c|c|c|c|}
\hline Dose (Gy) & pH 5 & pH 7 & pH 9 \\
\hline 0 & 2.478 & 2.453 & 2.429 \\
\hline 200 & 1.589 & 1.3 & 1.15 \\
\hline 400 & 0.952 & 0.811 & 0.653 \\
\hline 600 & 0.62 & 0.51 & 0.43 \\
\hline 800 & 0.48 & 0.39 & 0.3 \\
\hline 1000 & 0.4 & 0.32 & 0.2 \\
\hline
\end{tabular}

Table 6: Absorbance of methylene blue for post irradiation after 24 hours with $\mathrm{TiO}_{2}$

\begin{tabular}{|c|c|c|c|}
\hline Dose (Gy) & pH 5 & pH 7 & pH 9 \\
\hline 0 & 2.496 & 2.445 & 2.44 \\
\hline 200 & 1.086 & 1 & 1.307 \\
\hline 400 & 0.58 & 0.48 & 0.562 \\
\hline 600 & 0.452 & 0.4 & 0.264 \\
\hline 800 & 0.303 & 0.31 & 0.2 \\
\hline 1000 & 0.21 & 0.266 & 0.09 \\
\hline
\end{tabular}


Military Technical College

Kobry El-Kobbah, Cairo, Egypt

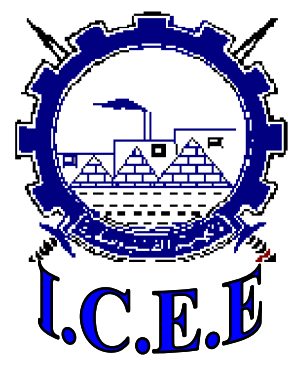

$5^{\text {th }}$ International Conference on

Chemical \& Environmental Engineering 25 - 27 May, 2010. 